\title{
Sulama ve drenaj kanalları ağaçlandırmalarında kullanılabilecek bazı hızlı gelişen yapraklı türlerin belirlenmesi (Şanlıurfa-Harran örneği)
}

\author{
Hüseyin KARATAY (Orcid: 0000-0003-4443-6693) ${ }^{* 1}$, Ali OKUR (Orcid: 0000-0002-8070-4950) \\ ${ }^{1}$ Güneydoğu Anadolu Ormancılık Araştırma Enstitüsü Müdürlüğü, ELAZIĞ \\ "Sorumlu yazar/Corresponding author: huseyinkaratay@ogm.gov.tr, Geliş tarihi/Received: 27.07.2017, Kabul tarihi/Accepted: 05.12.2017
}

$\ddot{\mathbf{O z}}$

Bu çalışma GAP bölgesinde Şanlıurfa-Harran ovasının Akören köyü civarında yapılmıştır. Araştırma çalışmasıında bölgede yaygın bulunan sulama veya drenaj kanalları ile tarım alanları arasında kalan tampon alanlarda yetiştirilebilecek bazı hızlı gelișen yapraklı türleri belirleme amaçlanmıștır. Denemede, karakavak türünün Kocabey (77/10), Anadolu (TR-56/75) ve 92.126 no'lu klonlar1, sögüt türlerinden 62.012 (Salix alba) ve 84/3 (S. alba) klonlar1 ile NZ.1001 (S.matsudana x S. alba) melez orijini, Eucalyptus camaldulensis türünün 7046 no'lu Avustralya orijini, Firat kavağının (Populus euphratica Oliv.) Birecik/Şanlıurfa orijini ve akkavak (Tunceli orijini) kullanılmıştır. Deneme deseninde, çapraz gelecek şekilde iki sıralı fidan dikimleri yapılmıştır. Denemede 5. yıl ölçme ve gözlemlerde çap, boy, böcek zararı ve yaşama yüzdeleri değerlendirilmiştir. Buna göre, okaliptüsün 7046 no'lu orijini başta olmak üzere karakavağın Kocabey klonu ve Fırat kavağının Birecik/Şanlıurfa orijini başarılı bulunmuştur. Bunlardan, Türkiye'de ilk defa bir ağaçlandırma çalışmasında kullanılan Fırat kavağı, iyi bir çap ve boy gelişiminin yanında, yaşama yüzdesi (\%100) bakımından diğer tür ve orijinlere göre daha başarılı bir performans göstermiştir. Harran/ Şanlıurfa bölgesinde bu üç tür, özellikle okaliptüste ilk yıllarda görülebilecek don tehlikesi dikkate alınarak sulama imkânı olabilecek alanlarda ağaçlandırma çalışmalarında kullanılabilir. Okaliptüs, don zararının kısmen daha az sıklıkta ve düşük şiddette görüldüğg̈ özellikle Şanlıurfa il merkezinin güneyinde kalan Viranşehir, Akçakale, Ceylanpınar ve Harran'ın güney kesimlerinden başlamak üzere sulama ve benzer şekilde drenaj kanalları veya su alabilen yol kenarlarında kullanılabilir. Dikimler, alanın genişliğine ve yörenin koşullarına bağlı olarak 1-3 sıra veya galeri şeklinde uygulanabilir.

Anahtar Kelimeler: Ağaçlandırma, Harran, hızlı gelişme, sulama - drenaj kanalları, yapraklı türler

\section{Determining some of the fast-growing broadleaved species that can be used in afforestation along irrigation channels (Şanlıurfa-Harran sample)}

\begin{abstract}
This study was carried out in the GAP region near Akören village of Şanlıurfa-Harran plain. The research study aimed to identify some of the fast-growing broadleaved species that could be grown in buffer areas between agricultural areas and irrigation or drainage channels that are common in the region. In the experiment, Kocabey clone (77/10), Anadolu (TR-56/75) and 92.126 clones of black poplar (Populus nigra), 62.012 (Salix alba) and 84/3 (S. alba) and NZ.1001 (S. matsudana $x$. alba) hybrid clone of salix species, Australian origin of Eucalyptus camaldulensis no.7046, Euphrates poplar (Populus eupratica Oliv.) of Birecik/Şanliurfa origin and white poplar (P. alba) of Tunceli origin were used. The seedlings were planted in two rows and crosswise in the experimental design. In the $5^{\text {th }}$ year of the experiment, the diameter, height, insect damage and survival percentages were evaluated. According to them, especially the origin of the eucalyptus no. 7046, Kocabey clone of black poplar and Birecik/Sanliurfa origin of the euphrates poplar were found to be successful. Among these species, the Euphrates poplar which was used for the first time in the afforestation activity in the Southeastern Anatolia region showed a better performance than the other species and origins regarding survival percentage (100\%) as well as good diameter and height development. In Harran/Şanlıurfa region, these 3 species can be used in afforestation activities in areas where irrigation may be possible, especially considering the frost hazard that can be seen in the first years of eucalyptus. Eucalyptus species can be used near the irrigation and similar drainage channels or roadsides with water, starting from the southern part of Viranșehir, Akçakale, Ceylanpınar, and Harran located in the south of Sanlıurfa province where frost damage is seen less frequently and less severely. Depending on the width of the area and conditions of the region, the plantings can be applied in 1 to 3 rows or as a gallery.
\end{abstract}

Keywords: Afforestation, broadleaved species, fast growing, Harran, irrigation - drainage channels

To cite this article (Atıf): KARATAY, H, OKUR, A . "GAP bölgesinde sulama ve drenaj kanalları ağaçlandırmalarında kullanılabilecek bazı hızlı gelişen yapraklı türlerin belirlenmesi”. Ormancıllk Araştırma Dergisi 5 (2018): 1-14

DOI: https://doi.org/10.17568/ogmoad.331281 


\section{Giriş}

Türkiye orman alanları, toplam alanının \%28,6’sını kaplamaktadır (Anonim, 2015). Ancak, toplam üretilen yapacak ve yakacak odun miktarı talebi karşılayamamaktadır. Diğer yandan kurulan barajlarla birlikte sulu tarıma geçilen geniş düzlüklere sahip 9 ili (Adıyaman, Batman, Diyarbakır, Gaziantep, Kilis, Mardin, Şanlıurfa, Siirt ve Şırnak) kapsayan GAP (Güneydoğu Anadolu Projesi) bölgesi son zamanlarda kısa idare süreli hızlı gelişen ağaç plantasyonları için çok yönlü yararlanma imkanı bulunan alternatif bir yetişme ortamı olarak önem kazanmıştır. GAP ile bölgede Şanlıurfa başta olmak üzere Fırat ve Dicle havzalarının yer aldığ 9 ilde yaklaşık 2,74 milyon hektar tarım alanının sulanması amaçlanmıştır. 2012 sonu itibariyle GAP Bölgesi 2.805.540 hektar sulama alanına sahip olup bu alanlarda toplam $62.788 \mathrm{~km}$ klasik kanal ve kanalet, $24.775 \mathrm{~km}$ drenaj kanalı olmak üzere toplam $87.563 \mathrm{~km}$ potansiyel alan mevcuttur. Bunların yanında ana yollar ve $60.000 \mathrm{~km}$ 'yi geçen servis yolları ve bu tesisler ile tarım alanları arasında kalan alanlar düşünüldüğünde farklı genişlikte galeri şeklinde binlerce km ağaçlandırılabilecek alan bulunmaktadır (Anonim, 2006; Anonim2012).

GAP bölgesinin birçok yerinde olduğu gibi dünyanın en verimli tarım arazilerinden biri olan Harran Ovas1 150.000 hektar sulama alanına sahiptir (Anonim, 2004). Harran ovası topoğrafik olarak çevresine göre çukur bir fizyografik yapıya sahiptir. Ova, genellikle Pleyistosen-Holosen alüviyallerinden meydana gelmiştir. Harran Ovası ve Suriye boyunca alüviyal düzlükleri ve nehir konglomeralarındaki çamur, kum ve çakıl yığıntıları Pleyistosen-Holosen zamanında meydana gelmiş ve depresyonların dolması ile oluşmuş birikintileri içermektedir (Dinç ve ark., 1988). Geniş düzlüklere sahip tarım yapılan Harran ovas1 genel olarak derin ancak, ağır toprak yapısına sahiptir. Ovada bilinçsiz bir şekilde yapılan sulama yüzünden tuzlanma (Anonim, 2004) ve bununla birlikte drenaj problemi başlamıştır. 2001 yılı sonu itibariyle Harran ovasında yeraltı su seviyesine bağlı olarak ortaya çıkan tuzlanma ve taban suyu problemi olan alanların toplamı 29.700 ha civarındadır. Drenaj sularının miktarını azaltmak için alınabilecek önlemlerden biri de belirli alanların tarımsal ormancılık faaliyetlerine ayrılması şeklinde düşünülebilir (Aydoğdu, 2006). Diğer yandan günümüzde 20'den fazla baraj ve hidroelektrik santrali ile 1,7 milyon ha sulama potansiyeli bulunan GAP bölgesi Türkiye alanının yaklaşı \% 10'unu kaplamakta ve genel kapsamda ağaçlandırma potansiyeli 400.000 ha olduğu düşünülmektedir (Birler ve Koçer, 1992). Buna rağmen bölgede, bu potansiyelin ancak \% 10'luk kısmı kullanılabilmiştir. Öte yandan günümüzde bölgede yapılan tarımla birlikte tarım ürünlerinin hasadı, depolanması, ambalaj ve nakli gibi aşamalarda ve diğer kullanımlar için odun hammaddesi kaynağ1 ihtiyacın 1/10'undan daha düşük seviyedir. Bölgede, yapılan barajlarla birlikte çok yönü yararlanmayı sağlayacak olan hızlı gelişen ağaç türleri ile yapılacak endüstriyel plantasyonlara ihtiyaç bulunmaktadır. Bu gereksinimler farklı dönemlerde yapılmış; [Aslan (1991), Birler ve Koçer (1992), Ayberk (1996), Uğurlu (1998), Toplu (1998), Toplu ve ark (2001), Öner (2002), Aslan ve Gökdemir (2005), Toplu ve Karatay (2006)] bilimsel çalışmalarla desteklenmektedir.

Ağaçlandırma çalışmalarına yön vermek, birim alanda verimi artırmak gibi amaçlarla farklı genetik yapıya sahip olduğu varsayılan tohum kaynakları farklı yetişme ortamlarında denenerek en iyi adaptasyon ve büyümeyi yapan tohum kaynakları, diğer bir deyimle orijinler belirlenmektedir. Yine bu sayede belirli bir bölgeye ait orijinlerin ya da genotiplerin coğrafik olarak ne kadar uzağa transfer olabileceği yine orijin denemeleri ile ortaya konmaktadır. Bunun gibi farklı amaçlarla orijin, klon veya tür denemelerine ilişkin araştırma ve uygulama çalışmalarının yapılması ve potansiyeli olan GAP yöresinde halkın katılımının sağlanması gerekmektedir. Bölgede baraj sulaması ile birlikte ağaçlandırmalarda sulu ortamda kullanılabilecek bazı ağaç türlerine ilişkin yeterli çalışma bulunmamaktadır. Son yıllarda okaliptüs ağacının enerji amaçlı üretimi, uçucu yağlarından yararlanılması ve doğal arıtımda kullanılabilmesi nedeniyle gün geçtikçe önemi artan bir bitki konumuna gelmiştir (Karsavuran ve ark., 2007). Bu türün yanında tuzluluk ve yüksek taban suyu problemi olan yerlerde Fırat kavağı ve diğer bazı türler üzerinde çalışmalar yoğunlaşmıştır.

GAP bölgesinin temel taşlarından biri olan ve önemli ağaçlandırma potansiyeli bulunan Şanliurfa'nın Harran ovası sinırında yapılacak bu çalışmada hızlı gelişen kavak, sögüut ve okaliptüs türlerine ait farklı klonlar ve orijinler kullanılmıştır. Bunlardan, Dünya'da kültürü yapılan ve Türkiye'de ticari amaçla yetiştirilen türlerin başında kavak cinsine ait türler gelmektedir. Ülkemizde, kavak türlerinden karakavak, akkavak, titrek kavak ve Fırat kavağı doğal olarak bulunmaktadır. $\mathrm{Bu}$ kavak türlerinden en yaygın olanı ise karakavak türü (Populus nigra) olup Anadolu'da halk arasında geleneksel olarak yetiştirilmekte ve geniş bir varyasyona sahip bulunmaktadır. Günümüzde bu varyasyondan yararlanılarak birim alandan daha yüksek verim almaya yönelik olarak genelde çelikle rahatlıkla üretilebilen türlerde özellikle kavak ve söğüt türlerinde klonal ıslah çalışmaları yapılmak- 
tadır. Bilindiği gibi klon, aynı ana ağaçtan alınan çeliklerden vejetatif yolla üretilen ve aynı genotipe sahip döllerin tamamı olarak nitelenmektedir. Islah çalışmalarında, ıslah değeri yüksek genetik özelliklere sahip klonlar seçilerek tescil edilmekte ve geçerli bir klon adı almaktadır. Bu ıslah çalışmaları sonucu ülkemizin farklı bölgelerinde başarılı bulunan başlica Anadolu (TR-56/75), Gazi (TR56/52), Kocabey (TR-77/10) ve Geyve (67.001) gibi karakavak klonları bulunmaktadır. Bu klonların bazıları bu çalışmada kullanılmıştır. Bu klonların yanında ülkemizde doğal rastlanan akkavak ile Dicle ve Fırat nehirleri ve kollarında yoğun yayılış gösteren, sıcak iklime ve tuzluluğa dayanıklı Firat kavağı kullanılmıştır.

Araştırmada kullanılan E. camaldulensis türünün ait olduğu Okaliptüs cinsi 700'ü aşan türü içerir ve ağırlıklı olarak güney yarımkürede bulunur (Myburg ve ark., 2006). Bataklıkların kurutulması amaciyla kullanılmasının yanında odunu yap1 kerestesi, yer döşemesi, maden direği, tekne yapımı, karoser yapımı, mobilyacılık, kaplama ve kontrplak, kağıt hamuru, enerji odunu, odun kömürü, ambalaj sandığ 1 , iç dekorasyon, dolgu malzemesi, doğramacılık ve travers, yonga levha, direk ve kazık, oyuncak, tornacılık ve müzik aletleri gibi bir çok alanda kullanılmaktadır (Gürses, 1992; Yaltır1k ve Efe, 2000; Toplu ve ark., 2001). Bu türe ait farklı orijinler GAP bölgesinde susuz ortamda denenmiş ve bunlardan, E. camaldulensis Dehn'nin kuraklığa ve dona dayanaklı olduğu belirlenmiştir (Gülbaba, 1990).

Çalışmada kullanılan söğüt klonlarının içinde yer aldığ1 söğüt cinsine ait Türkiye'de doğal olarak 20 'den fazla türü bulunmakta ve kavak ile birlikte her yerde rastlanabilmektedir. Sanayide başlıca selüloz ve kağıt yapımında olmak üzere, sepet yapımı, çit yapımı, rüzgar perdesi, yakacak, süs bitkisi ve hayvan yemi olarak da kullanılmaktadır. Biomas üretimi ve enerji amaçlı tesislerde, hızlı büyümesi, sürgün verme kapasitesinin yüksek olması ve vejetatif olarak kolay üretilmesi gibi karakteristikleri yönünden enerji plantasyonları tesisine uygun tür olarak görülmektedir (Ericson, 1984; Ager ve ark., 1986). Birçok ülkede hızlı gelişen türlerle tesis edilen endüstriyel amaçlı plantasyonlarda kavakların yanında söğütlere de oldukça geniş yer verilmektedir. $\mathrm{Bu}$ araştırmada kullandığımız NZ. 1001 (Salix matsudana x Salix alba) sögüut melez klonu, Yeni Zellanda'nın hibrit söğütü olarak bilinmekte ve çoğunlukla toprak muhafaza ve klon seleksiyonunda kullanılmaktadır (Anonim, 2013a).

Bu çalışmada, Harran yöresinde odun hammaddesinin artımına katkı sağlayacak, en iyi büyümeyi sağlayan, tutma başarıları yüksek, hastalıklara da- yanıklı ve bölgeye uyum gösteren, aynı zamanda tarım alanlarının kenarlarında, sulama ve drenaj kanal ve kanaletleri ile yol boylarında kullanılabilecek bazı yapraklı ağaç türlerine ait orijin ve klonların tespiti ve gelişimlerine ilişkin bilgiler ortaya konması amaçlanmıştır. Şanlıurfa ilinin Harran yöresinde ve benzer sulama yapılan alanlarda başarılı olan türler kullanılarak başta odun ürünü elde etmek ve sürdürülebilir faydalanmayı sağlamak, verimliliği artırmak çalışmanın ana hedeflerindendir. Böylece daha geniş alanlarda yapılacak ağaçlandırmalarla bölgenin odun ürünü talebinin karşılanmasında ve aynı zamanda sosyo-ekonomik yönden yöre halkına ve dolayısıyla ülke ekonomisine katkı sağlanabilecektir.

\section{Materyal ve Yöntem}

\subsection{Materyal}

\subsubsection{Araştırma alanının tanıtımı}

\subsubsection{Araştırma alanının yeri ve toprak yapısı}

Deneme sahası Şanlıurfa ili, merkez ilçeye bağlı Harran yakınındaki Akören Köyü batısında özel şahıs arazisinde, Atatürk Barajı sulama alanı içerisinde yer almaktadır. Deneme sahası Harran ovas1 devamında ovanın güneydoğu istikametinde tarla kenarı ile DSI'ye ait açık beton sulama kanaletleri arasındaki doğu batı istikametinde yaklaşı 10 $\mathrm{m}$ genişliğindeki asfalt yola paralel olarak devam eden düz bir alanda (Anonim, 2013b) iki sıralı olarak kurulmuştur (Şekil 1).

Deneme sahasında açılan toprak profilinde ve 90 cm'ye kadar alınan toprak örneklerinden toprağın $120 \mathrm{~cm}$ 'den daha derin ağır tekstürlü tekdüze bir yapıya sahip olduğu görülmüştür. Analiz sonuçlarına göre, pH: 7,45 ile 8,15 arasında S2-S3 sınıfında (uygun ve marjinal uygun) toprak türü olarak kil s1nıfında yer almıştır. Toprak tuzluluğu 2 milimhos/ cm'den daha düşük değerde olup tuzsuz sınıfında ve ancak tuz miktarı, çok hassas bitkilerin zarar görebileceği aralıkta bulunmaktadır. Total kireç \%28,35-29,73 arasında olup aktif kireç bakımından özellikle kavak yetiştiriciliği için S3 sınıfında marjinal uygun olan çok kireçli sınıfında bulunmuştur. Organik madde \%2,5 - 3,8 arasında olup çok uygundur. Toprak profilinde $\mathrm{P}_{2} \mathrm{O}_{5}(70,17-209,13 \mathrm{ppm})$, $\mathrm{K}_{2} \mathrm{O}(111,83-314,36 \mathrm{ppm})$ ve $\mathrm{Na}(34,69-49,39 \mathrm{ppm})$ bakımından zengin olduğu belirlenmiştir.

\subsection{2. İklim}

Deneme sahasına ait uzun yıllara ait iklim bilgileri için Şanlıurfa merkez verilerinden (Tablo 1), deneme çalışmasının devam ettiği 5 yıllık (20082012) ve uzun süreli Harran yöresi iklim verileri de denemeye en yakın Şanlıurfa Toprak ve Su Kay- 


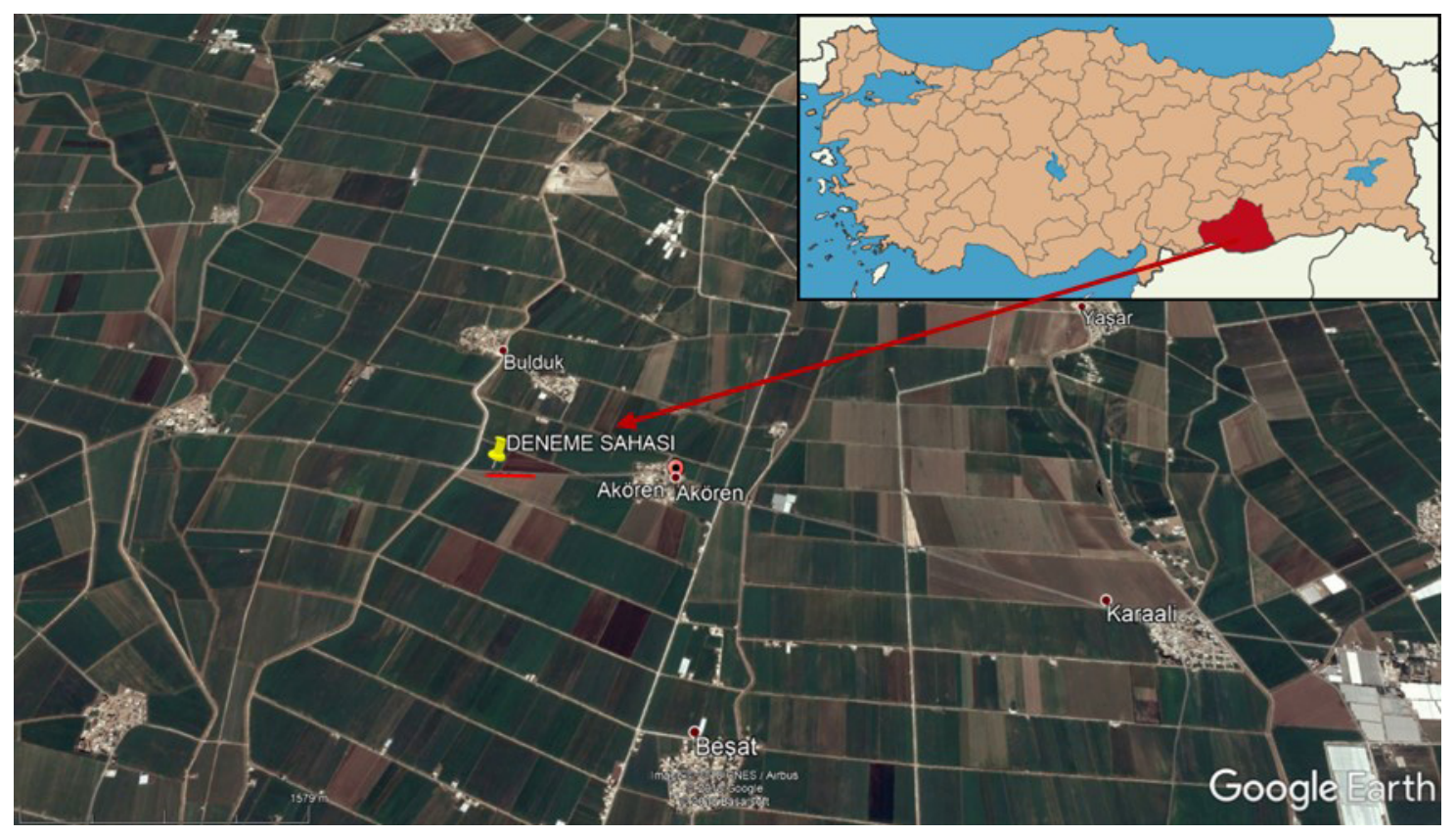

Şekil 1. Deneme sahasının kurulduğu Şanlıurfa Akören Köyü (Anonim, 2013b)

Figure 1. Akören Village of Şanlıurfa province where the experiment site was established (Anonymous, 2013b)

nakları Araştırma Enstitüsü’nün ölçüm istasyonu değerlerinden alınmıştır. Tablo 1'de görüldüğü gibi ortalama en yüksek sıcaklık Haziran-Eylül ayları arasında olup $30^{\circ} \mathrm{C}$ 'nin üzerinde bulunmaktadır. 52 yıllık verilere göre nadir de olsa erken ve geç donlara rastlanabilmektedir. Yağışlar genel olarak Aralık-Mart aylarında düşmekte ve en düşük yağış ise Haziran-Eylül ayları arasında (4 aylık sürede aylık 2,4-4,8 kg/m²) gerçekleşmektedir (Tablo 1). 2008-2012 yılları arasında ise en yüksek sıcaklık, Haziran-Eylül ayları arasında $25{ }^{\circ} \mathrm{C}$ 'nin üzerinde kaydedilmiştir. Araştırmanın devam ettiği süre içerisinde öncelikle 2010 ve 2008 yıllarında ortalama maksimum yüksek sıcaklıklar yaşanmıştır. En düşük sıcaklıklar ise vejetasyon mevsimi dışında Aralık-Şubat ayları arasında, ortalama $10^{\circ} \mathrm{C}$ 'nin altında gerçekleşmiştir. Deneme süresince vejetasyon mevsiminde minimum sıcaklık değerleri genel olarak sıfırın altında gözlenmezken 2008 yılı Şubat ayında $-3,1^{\circ} \mathrm{C}, 2009$ yılı Ocak ayında $-4,7^{\circ} \mathrm{C}$ ve 2011 yılının Kasım ayında $-0,4^{0} C^{\prime} l i k$ ekstrem bir sıcaklık değeri kaydedilmiştir (Anonim, 2013c).

Şanlıurfa iline ait 1962-2012 y1lları arasında yıllık toplam yağış ortalaması $467,6 \mathrm{~kg} / \mathrm{m}^{2}$ iken deneme sahasına çok yakın bir yer olan Harran yöresinde 1979-2011 yılları arasında ortalama yağış miktarı $339,7 \mathrm{~kg} / \mathrm{m}^{2}$ olmuştur (Tablo 1). 2008-2011 yılları arasında ise 184,7 ile $234,1 \mathrm{~kg} / \mathrm{m}^{2}$ arasında çok daha

Tablo 1. Şanlıurfa iline ait uzun yıllar iklim verileri

Table 1. Long Term Climate data of Sanlıurfa province

\begin{tabular}{|c|c|c|c|c|c|c|c|c|c|c|c|c|}
\hline Şanlıurfa & 1 & 2 & 3 & 4 & 5 & 6 & 7 & 8 & 9 & 10 & 11 & 12 \\
\hline & \multicolumn{12}{|c|}{ Uzun yıllar içinde gerçekleşen ortalama değerler (1960 - 2012) } \\
\hline Ortalama sicaklık $\left({ }^{\circ} \mathrm{C}\right)$ & 5,6 & 6,9 & 10,9 & 16,1 & 22,2 & 28,2 & 31,9 & 31,2 & 26,8 & 20,2 & 12,7 & 7,5 \\
\hline Ortalama en yüksek sıcaklık $\left({ }^{\circ} \mathrm{C}\right)$ & 10,0 & 11,8 & 16,5 & 22,2 & 28,6 & 34,6 & 38,7 & 38,2 & 33,8 & 26,9 & 18,5 & 12,0 \\
\hline Ortalama en düşük sıcaklık ( $\left.{ }^{\circ} \mathrm{C}\right)$ & 2,3 & 2,9 & 6,2 & 10,5 & 15,6 & 20,8 & 24,4 & 24,0 & 20,1 & 14,8 & 8,4 & 4,1 \\
\hline Ortalama güneşlenme süresi (saat) & 4,0 & 5,6 & 6,2 & 7,4 & 10,1 & 12,2 & 12,3 & 11,3 & 10,1 & 7,5 & 5,5 & 4,0 \\
\hline Ortalama yağışlı gün sayısı & 12,4 & 11,3 & 10,9 & 9,8 & 6,5 & 1,5 & 0,3 & 0,2 & 0,9 & 5,3 & 8,1 & 11,2 \\
\hline Aylık toplam yağ 1 ş ortalaması $\left(\mathrm{kg} / \mathrm{m}^{2}\right)$ & 86,5 & 71,2 & 64,3 & 48,0 & 28,3 & 4,1 & 2,4 & 3,8 & 4,8 & 27,9 & 47,5 & 78,8 \\
\hline
\end{tabular}

Yıllık toplam yağış miktarı ortalaması: $467,6 \mathrm{~kg} / \mathrm{m}^{2}$

Uzun yıllar içinde gerçekleşen en yüksek ve en düşük sıcaklık değerleri (1960 - 2012)

\begin{tabular}{lcccccccccccc}
\hline En Yüksek Sicaklık $\left({ }^{\circ} \mathrm{C}\right)$ & 21,6 & 22,7 & 29,5 & 36,4 & 40,0 & 44,0 & 46,8 & 44,8 & 42,0 & 37,0 & 29,4 & 26,0 \\
En Düşük Sicaklık $\left({ }^{\circ} \mathrm{C}\right)$ & $-8,0$ & $-9,6$ & $-7,3$ & $-3,2$ & 6,0 & 10,0 & 16,0 & 16,0 & 11,2 & 2,5 & $-2,7$ & $-6,4$ \\
\hline
\end{tabular}


düşük seviyede yağış görülmüştür. Şanlıurfa ve ilçelerinin 2008-2012 yıllarını kapsayan kuraklık analizinde, Standart Yağış İndeksi Metodu (SPI)'na göre kuraklık indisi ve sınıflandırmasında, şiddetli kurak (2010) ile orta nemli (2012) arasında değerler almıştır (Anonim, 2013c).

\subsubsection{Deneme türleri}

$\mathrm{Bu}$ denemede materyal olarak Eucalyptus camaldulensis Dehnh., Populus euphratica Oliv. ve Populus alba türlerinden birer tane orijin ile 3 karakavak ve 3 söğüt klonu kullanılmıştır. Bunlardan Fırat Kavağı (Populus euphratica Oliv.: ŞanlıurfaBirecik orijini), akkavak (Populus alba L.: Tunceli orijini: Mazgirt/Tunceli-Kovancilar yolu 13,3 km), karakavak türüne (Populus nigra L.) ait Kocabey (TR-77/10), Anadolu (P. thevestina cl. TR. 56/75) ve N.92.126 (Bilecik-Osmaneli) klonları kullanılmıştır. Söğüt (Salix) türlerinden Salix alba (62.012: Akyaz1-Vakıflar), Salix alba (84/3: Edirne-Topsögüt) klonları ve NZ.1001 (Salix matsudana x Salix alba): Yeni Zellanda'nın melez söğüt orijini ve Okaliptüs (Eucalyptus camaldulensis Dehnh. türüne ait 7046 no'lu Wiluna/Avustralya orijini kullanılmıştır. Bu orijine ait fidanlar Ceyhan/Adana'da kurulmuş bulunan plantasyon sahasından toplanan tohumların ekimi ile elde edilmiştir.

\subsection{Yöntem}

Rastlantı blokları deneme düzenine göre 4 blok halinde ve her blokta her bir tür için 6 fidan kullanılmıştır. Dikimler 2 sıra halinde, sıralar birbirine pa- ralel olarak tarla kenarı boyunca doğu-batı yönünde bir sıradaki fidanlar diğer sıradaki fidanlarla aynı hiza yerine çaprazına gelecek şekilde yapılmıştır. Fidan siraları arası mesafe ve sira üzeri 3'er metre olacak şekilde deneme deseni kurulmuştur (Şekil 2).

Araştırma sahası, şahıs tarlasının kuzey sınırında doğu-bat1 yönünde iki sıra boyunca yapıldığ1 için tarla boyunca kisitlı alan olduğundan toplam 9 farkl1 materyal (klonlar ve orijinler) x 6 fidan x 4 blok x 3 m (324 m'lik 2 sıra) olarak tesis edilmiştir. Ancak, denemenin 4. bloğundaki fidanlar insan baskıs1 gördüğünden 3 blok üzerinden değerlendirme yapılmıştır. Değerlendirmede türlere ait klonlar ve orijinler işlem olarak ele alınmıştır.

Klon ve orijinler arasında fidanların dip çap (toprak seviyesinden $5 \mathrm{~cm}$ üstten), göğüs çapı (1,30 m) $\mathrm{mm}$ hassasiyetinde çap ölçerle, boy ise cm hassasiyetinde elektronik boy ölçerle belirlenmiştir.

Böcek zararı için ağacın hayatiyetine etkisi bakımindan daha ayrıntılı ve farkların daha belirgin olması amaciyla genel olarak yapılan böceklenme var (1) ve yok (0) değerlendirmesi yerine Toplu (1997)'nun karakavaklar için kullandığı 5 seviyede oluşturulan ıskala yöntemine göre $(5=$ böcek zararı görmemiş, $4=$ az zarar görmüş $(\% 25), 3=$ orta düzeyde zarar görmüş ( $\% 50), 2=$ büyük oranda zarar görmüş (\%75) ve 1= tamamen (\%100) böcek zarar1na uğramış) göre değerlendirilmiştir. Ayrıca, blok düzeyinde fidan yaşama yüzdeleri değerlendirmeye alınmıştır.

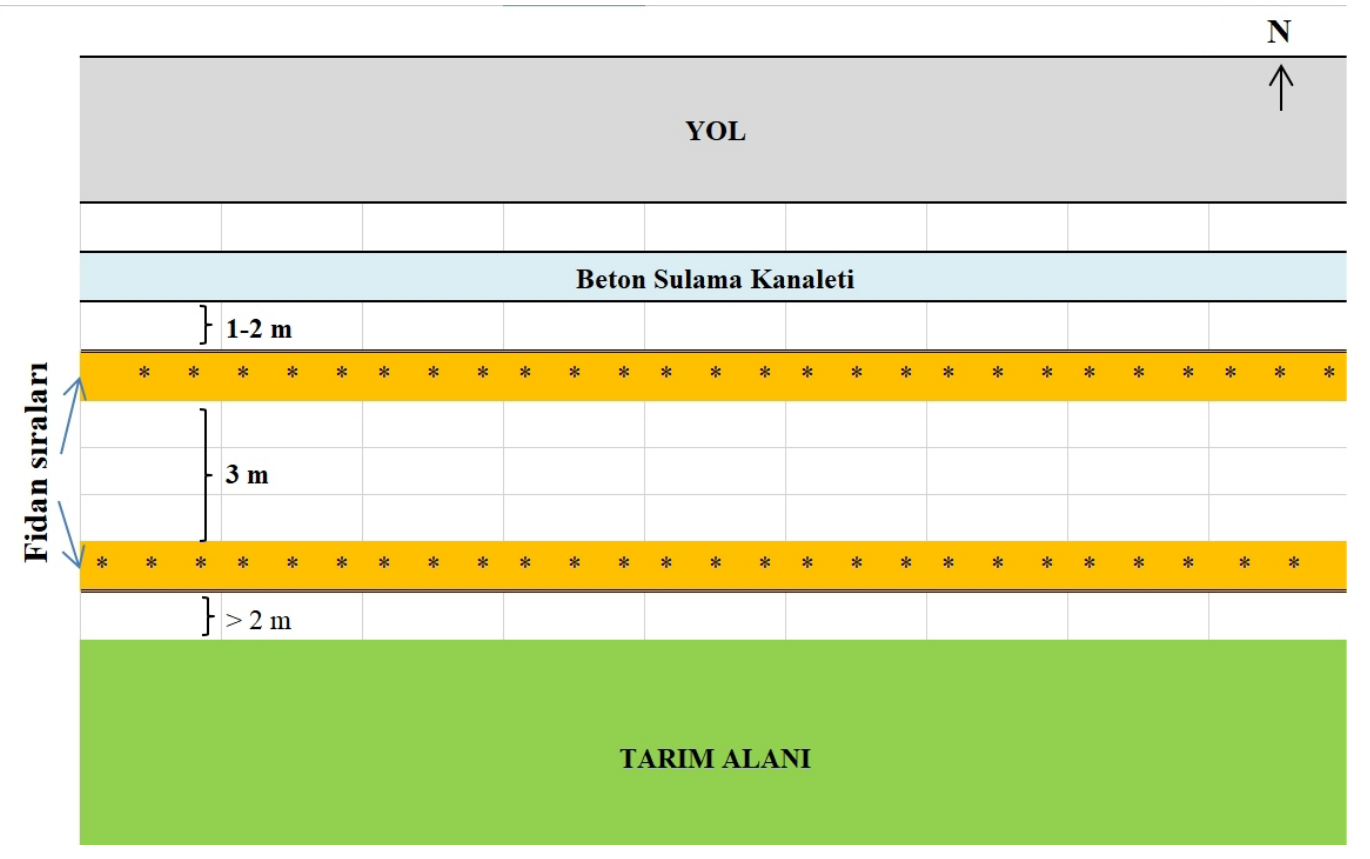

Şekil 2. Harran/Şanlıurfa'da tarım alanı kenarında iki sıralı olarak kurulan deneme deseni Figure 2. Experimental design on the edge of agriculture area as two rows in Harran/Şanlıurfa 


\subsubsection{Verilerin değerlendirilmesi}

Verilerin analizi için Excel ve SPSS 20.0 istatistik paket programı (Anonim, 2017) kullanılmıştır. Türlere ait klon ve orijinlerin gelişimlerine ilişkin analizlerde, normal dağılıma uygun olmayan böcek zararı verilerine karekök dönüşümü ve yaşama yüzdeleri verilerine arc-sin dönüşümü (Ercan, 1997) yapıldıktan sonra varyans analizi aşağıdaki doğrusal modele göre yapılmıştır.

$y_{i j k}=\mu+B_{i}+C_{j}+I_{c i j}+e_{i j k}$

$\mathrm{Bu}$ formülde,

$Y_{i j k}=$ bir işlem için gözlenen bireysel ağacın değeri, $\mu=$ genel ortalamay1,

$B_{i}=$ blok i' nin tesadüf etkisi $C_{j}=$ klon/orijin j' nin tesadüf etkisi,

$I_{c i j}=\mathrm{i}$. bloktaki, j.klon/orijinin tesadüfi interaksi yon etkisi,

$e_{i j k}=\mathrm{i}$. bloktaki, j. klon/orijindeki, k. ağacın tesadüfi etkisidir.

Varyasyon analizi sonucu türlere ait klonlar ve orijinler arasında $\alpha=0,05$ önem düzeyinde farklılık tespit edilmesi durumunda gruplanmaları görmek üzere Duncan testi uygulanmıştır.

Karakavak hacim değerlendirmelerinde, Birler (2010)'da belirtilen yerli karakavaklar için kabuklu gövde hacmi (V), kabuklu göğüs çapı (D) ve ağaç tam boyuna $(H)$ göre, $V=f(D, H)$ fonksiyonu uyarınca hacim değerleri logaritmik olarak

$\log (V)=-1,4294+2,0447 \log (D)+0,92187 \log (H)$

şeklinde belirlenmiş ve logaritmik sayılar reel sayıya dönüştürülerek oluşan sistematik hatanın giderilmesi için f_1.00091412 düzeltme katsayısı faktörü (f) kullanı̄̄mıştır. Fırat kavağ 1 için de blok ortalama değerlerinden buna paralel hesaplamalar yapılmıştır. Bunun yanında okaliptüs için ise Yıldızbakan ve ark. (2007) çalışmaların okaliptüs baltalıkları için hesaplanan hacim tablolarından yararlanılarak hacim artım ve servet değerleri belirlenmiştir.

\section{Bulgular}

\subsection{Dip çap ve göğüs çapı}

Deneme sahasında 5 yıllık ölçümler neticesinde dip çap ve göğüs çapı değerlerine yapılan varyans analizinde (Tablo 2 ve 4), türlere ait klonlar ve orijinler arasında $\mathrm{p}<0,001$ olasılık düzeyinde önemli farklılıklar tespit edilmiştir. Bununla birlikte dip ve göğüs çaplarında bloklar etkisiz çıkmıştır. Dip çapa göre yapılan Duncan testinde (Tablo 3) klonlar ve orijinler arasında en iyi gelişimi okaliptüs
$(15,18 \mathrm{~cm})$ ve Firat kavağı $(13,27 \mathrm{~cm})$ göstererek ilk grupta yer almışlardır. Karakavağın Kocabey klonu ise $12,29 \mathrm{~cm}$ dip çap ile 2. grupta yer almıştır. En düşük dip çap gelişimini ise akkavak $(4,87 \mathrm{~cm})$ ve N.92.126 karakavak klonu $(5,00 \mathrm{~cm})$ yapmıştır.

Tablo 2. Klonlar ve orijinlerin dip çaplarına ait varyans analizi sonuçları

Table 2. Result of ANOVA for base diameter of clones and origins

\begin{tabular}{lcrc}
\hline $\begin{array}{l}\text { Varyasyon kaynağ1 } \\
\text { (Dip çap) }\end{array}$ & SD & KO & F \\
\hline Klonlar ve orijinler & 8 & $3.872,220$ & $22,998^{* * *}$ \\
Blok & 2 & 247,864 & $1,472 \mathrm{~ns}$ \\
Hata & 16 & 168,370 & \\
Genel & 26 & & \\
\hline$\alpha=0,05$ önem düzeyi & & \\
SD: Serbestlik derecesi, KO: Kareler ortalaması, F: F değeri
\end{tabular}

Tablo 3. Klonlar ve orijinlerin dip çaplarına ait Duncan test sonuçları

Table 3. Results of Duncan test for base diameter of clones and origins

\begin{tabular}{lcc}
\hline Klonlar ve orijinler & N & Dip çap $(\mathrm{mm})$ \\
\hline Okaliptüs & 3 & $151,76 \mathrm{a}$ \\
F. kavağ1 & 3 & $132,73 \mathrm{ab}$ \\
Kocabey & 3 & $122,89 \mathrm{bc}$ \\
NZ.1001 & 3 & $105,28 \mathrm{~cd}$ \\
Anadolu & 3 & $86,67 \mathrm{de}$ \\
S.84.003 & 3 & $84,56 \mathrm{de}$ \\
S.62.012 & 3 & $73,89 \mathrm{e}$ \\
N.92.126 & 3 & $49,98 \mathrm{f}$ \\
Akkavak & 3 & $48,67 \mathrm{f}$ \\
\hline
\end{tabular}

Duncan testi ( $\alpha=0,05$ önem düzeyi)

N: Örnek sayısı

Tablo 4. Klonlar ve orijinlerin göğüs çaplarına (1,30 m) ait varyans analizi

Table 4. Results of ANOVA for breast height diameter $(1,30 \mathrm{~m})$ of clones and origins

\begin{tabular}{lcrc}
\hline $\begin{array}{l}\text { Varyasyon kaynağ1 } \\
\text { (Göğüs çap1) }\end{array}$ & SD & \multicolumn{1}{c}{ KO } & \multicolumn{1}{c}{ F } \\
\hline Klonlar ve orijinler & 8 & $3.784,648$ & $49,579 * * *$ \\
Blok & 2 & 31,471 & 0,412 ns \\
Hata & 16 & 76,335 & \\
Genel & 26 & & \\
\hline
\end{tabular}

$\alpha=0,05$ önem düzeyi

Göğüs çapına göre yapılan Duncan testinde en yüksek çap gelişimini okaliptüs $(10,82 \mathrm{~cm})$ ve Firat kavağ $1(8,32 \mathrm{~cm})$ yaparak istatistiksel bakımdan farksız olarak ilk grupta yer alırken, Kocabey klonu $(7,75 \mathrm{~cm})$ ikinci grupta yer almıştır. 
En düşük performansı ise akkavak $(1,57 \mathrm{~cm})$ göstermiştir (Tablo 5). Deneme sahasında okaliptüsün 7046 no'lu orijinine ait yıllık $4 \mathrm{~cm}$ çap gelişimi gösteren bireylere de rastlanmıştır (Şekil 3).

Tablo 5. Klonlar ve orijinlerin göğüs çaplarına (1,30 m) ait Duncan test sonuçları

Table 5. Results of Duncan test for breast height diameter $(1,30 \mathrm{~m})$ of clones and origins

\begin{tabular}{lcc}
\hline Klonlar ve orijinler & N & Göğüs çapı $(\mathrm{mm})$ \\
\hline Okaliptüs & 3 & $108,2 \mathrm{a}$ \\
F. kavağ 1 & 3 & $83,2 \mathrm{~b}$ \\
Kocabey & 3 & $77,5 \mathrm{~b}$ \\
Anadolu & 3 & $33,1 \mathrm{c}$ \\
NZ.1001 & 3 & $24,4 \mathrm{~cd}$ \\
S.62.012 & 3 & $20,7 \mathrm{~cd}$ \\
S.84.003 & 3 & $18,3 \mathrm{~cd}$ \\
N.92.126 & 3 & $15,8 \mathrm{~d}$ \\
Akkavak & 3 & $15,7 \mathrm{~d}$ \\
\hline
\end{tabular}

Duncan testi $(\alpha=0,05$ önem düzeyi)

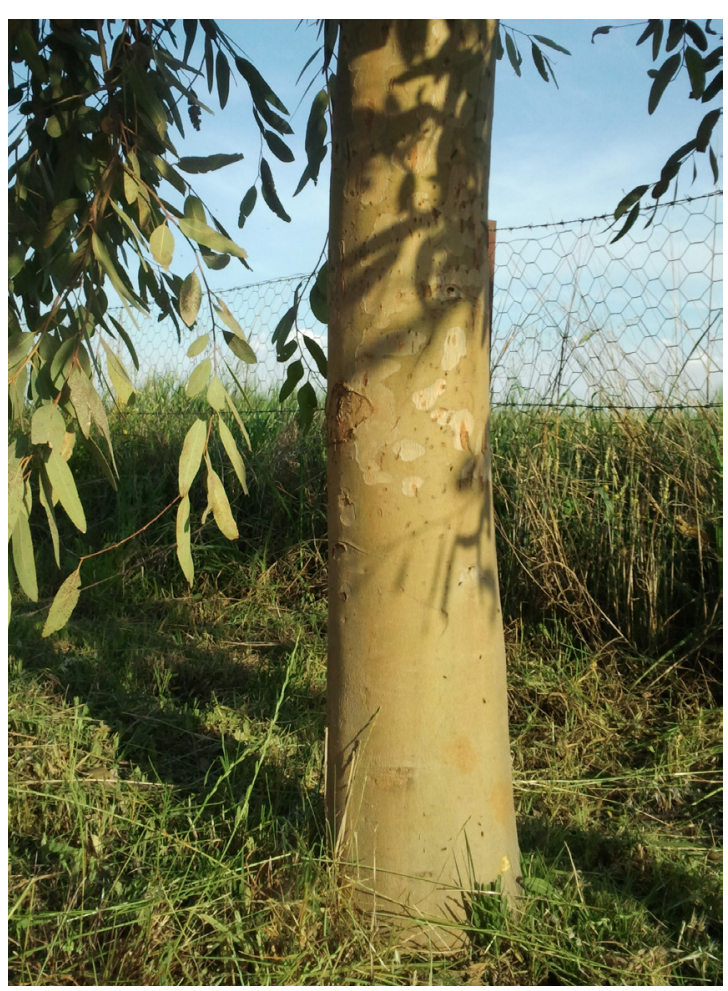

Şekil 3. Yıllık ortalama $4 \mathrm{~cm}$ çap gelişimi yapan okaliptüs (7046 no'lu orijin)

Figure 3. An eucalyptus (7046 numbered origin) tree grows $4 \mathrm{~cm}$ diameter on average per year

\subsection{Boy gelişimi}

Deneme sahasında türlere ait klonların ve orijinlerin 5 y1llık fidan boy gelişimine ait varyans analizinde boyları arasında $\mathrm{p}<0,001$ olasılık düzeyinde önemli farklılıklar çıkmıştır (Tablo 6). Bloklar arasında ise farklılık çıkmamıştır. Klonların ve orijinlerin boy farklılıklarına ait Duncan testinde (Tablo 7) okaliptüs 7,94 m boy ile en iyi gelişimi sağlayarak ilk grupta yer almıştır. Karakavağın Kocabey klonu $(6,57 \mathrm{~m})$ ve Firat kavağ1 $(5,50 \mathrm{~m})$ sirayla 2. ve 3. grupta yer almışlardır. En kötü performansı ise akkavak S.84.003 ve N.92.126 klonları yapmışlardir.

Tablo 6. Klon ve orijinlerin boy değerlerine uygulanan varyans analizi

Table 6. Result of ANOVA for height values of clones and origins

\begin{tabular}{lccc}
\hline Varyasyon kaynağı (Boy) & SD & KO & F \\
\hline Klonlar ve Orijinler & 8 & 9,526 & $32,761^{* * *}$ \\
Blok & 2 & 0,889 & $3,056 \mathrm{~ns}$ \\
Hata & 16 & 0,291 & \\
Genel & 26 & & \\
\hline$\alpha=0,05$ önem düzeyi & & &
\end{tabular}

Tablo 7. Klonlar ve orijinlerin boy değerlerine ait Duncan test sonuçları

Table 7. Result of Duncan test for breast height values of clones and origins

\begin{tabular}{lcc}
\hline Klonlar ve orijinler & $\mathrm{N}$ & Boy $(\mathrm{m})$ \\
\hline Okaliptüs & 3 & $7,94 \mathrm{a}$ \\
Kocabey & 3 & $6,57 \mathrm{~b}$ \\
Firat Kavağ 1 & 3 & $5,50 \mathrm{c}$ \\
Anadolu & 3 & $4,55 \mathrm{~d}$ \\
NZ.1001 & 3 & $3,79 \mathrm{de}$ \\
S.62.012 & 3 & $3,49 \mathrm{e}$ \\
N.92.126 & 3 & $3,28 \mathrm{ef}$ \\
S.84.003 & 3 & $3,18 \mathrm{ef}$ \\
Akkavak & 3 & $2,61 \mathrm{f}$ \\
\hline Duncan testi $(\alpha=0,05$ önem düzeyi)
\end{tabular}

Okaliptüsten sonra boylanma bakımından 2. sırada yer alan karakavağın Kocabey klonuna ait bir görüntü Şekil 4'te yer alırken, 3. sırada boylanma gösteren Firat kavağı da Şekil 5'te görülen gelişmeyi sağlamıştır.

\subsection{Fidan yaşama yüzdeleri}

Yaşama yüzdesi bakımından türlere ait klon ve orijinlere uygulanan varyans analizinde $p<0,001$ olasılık düzeyinde önemli farklılıklar olduğu blirlenmiştir (Tablo 8). Klon ve orijinlerin dönüşüm yapılmış yaşama yüzdesi verilerine Duncan testi (Tablo 9) uygulanmıştır. Dönüşüm yapılmamış yüzde değerlerine göre Fırat kavağı diğerlerine göre 


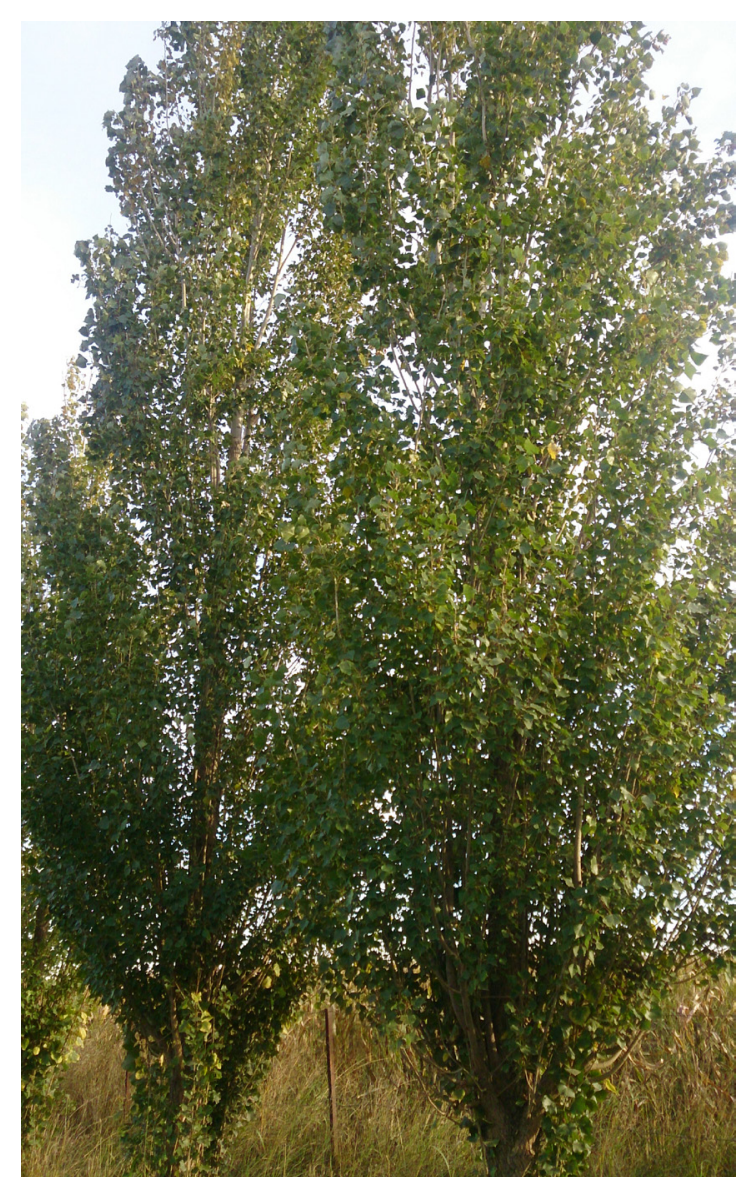

Şekil 4. Karakavağın Kocabey klonunda boy büyümesi (5. y11)

Figure 4. Height growth of Kocabey clone of black poplar (5th year)

önemli farkl1lık göstererek \%100 yaşama yüzdesi ile ilk sırayı almıştır. N.92.126 karakavak klonu (\%77,67), okaliptüsün 7046 no'lu orijini ile Kocabey klonu ikinci grupta ve aynı değerde $(\% 72,33)$; akkavak ile S.62.012 no'lu sögüt klonları ise \%28 seviyesinde yaşama yüzdesi ile son grupta yer alarak çok düşük yaşama yüzdesi göstermişlerdir. Deneme sahasında yapılan gözlemlerde okaliptüste ilk yılda görülen don etkisi, akkavak, karakavak ve söğüt klonlarında ağır toprak koşullarının yanında söğüt klonlarında oluşan gövde yanıkları ve bunun yanında karakavak ile birlikte söğütlerde görülen böcek zararı yaşama yüzdelerini etkilemiştir.

\subsection{Böcek zararı}

Deneme sahasının bulunduğu Harran çevresinde genel stres koşulları olarak ağır toprak şartları, yaz döneminde ekstrem yüksek sıcaklığın oluşması ve bunların yanında tarım alanlarında HaziranTemmuz aylarına rastlayan ekin hasat döneminde sulamanın kesilmesi neticesinde görülen su nok-

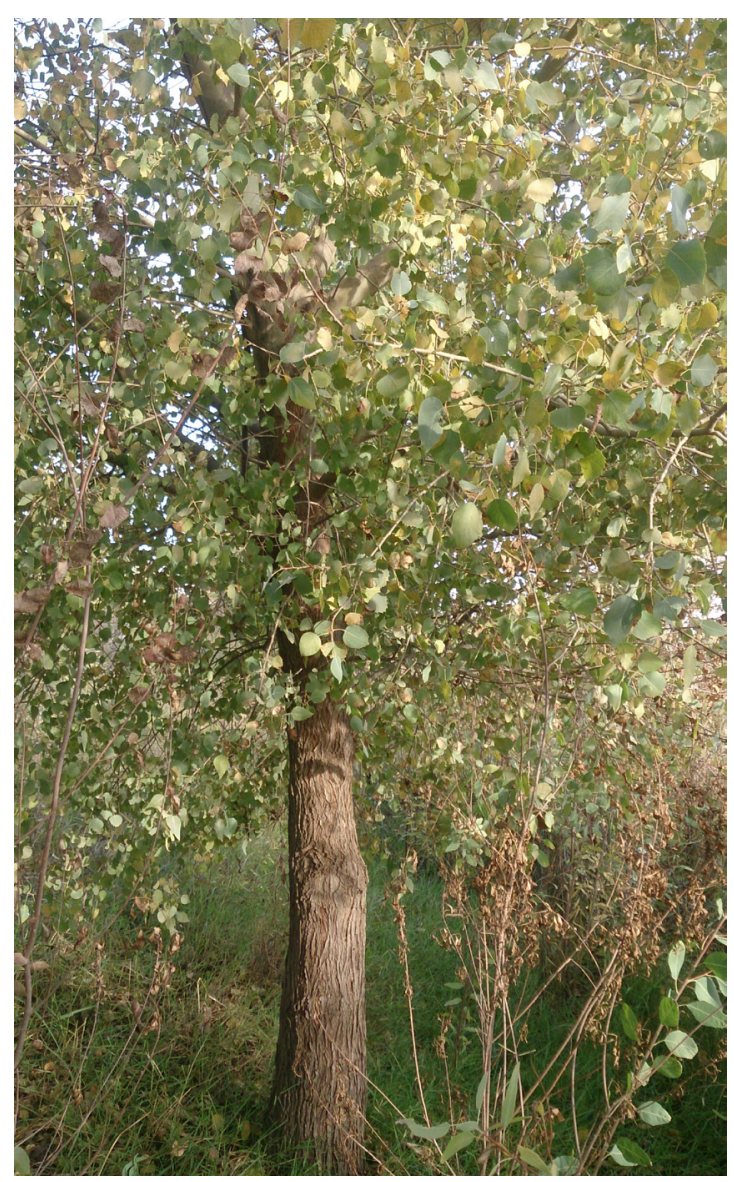

Şekil 5. Fırat kavağının 5. yıl boy büyümesi

Figure 5. Fifth year height growth of Euphrates poplar

sanlığı, özellikle söğüt ve kavak türleri başta olmak üzere uzun süreli yakıcı ve yüksek derecedeki güneşlenmeden dolayı ağaçlar strese girmekte ve büyüme kaybı, gövde yanıkları, böceklenme ve kuruma gibi farklı derecede etkilenmektedir. Deneme sahasında başlica gövde ve dallarda zarar veren böcek türlerinden Melanophila picta Pall. (Kavak süslü böceği) ve Sciapteron tabaniformis

Tablo 8. Fidan yaşama yüzdelerine ilişkin varyans analizi Table 8. Variance analysis for sapling survival percentage

\begin{tabular}{lcrc}
\hline $\begin{array}{l}\text { Varyasyon kaynağ } \\
\text { (Yaşama yüzdesi) }\end{array}$ & SD & \multicolumn{1}{c}{ KO } & F \\
\hline Klonlar ve orijinler & 8 & $1.088,292$ & $15,752^{* * *}$ \\
Blok & 2 & 245,253 & $3,550 \mathrm{~ns}$ \\
Hata & 16 & 69,089 & \\
Genel & 26 & & \\
\hline
\end{tabular}

$\alpha=0,05$ önem düzeyi

Rott. (Kavak odun arısı) kavak ve söğütlerde, köklerde zarar yapan Capnodis miliaris Klug. (Kavak 
kök süslü böceği) ise karakavaklarda rastlanmış ve bu böcekler farklı derecelerde zarar vermişlerdir.

Böcek zararına göre, türlere ait klon ve orijinlere uygulanan varyans analizinde (Tablo 10) önemli derecede fark bulunmuştur.

Tablo 9. Fidan yaşama yüzdelerine ilişkin Duncan testi Table 9. Duncan tests for sapling survival percentage

\begin{tabular}{llc}
\hline Klonlar ve orijinler & N & $\begin{array}{c}\text { Yaşama yüzdesi } \\
\text { (Arc-sin dön.) }\end{array}$ \\
\hline F. kavağ1 & 3 & $90,00 \mathrm{a}$ \\
N.92.126 & 3 & $62,19 \mathrm{~b}$ \\
Kocabey & 3 & $58,46 \mathrm{~b}$ \\
Okaliptüs & 3 & $58,46 \mathrm{~b}$ \\
Anadolu & 3 & $51,97 \mathrm{bc}$ \\
S.84.003 & 3 & $41,75 \mathrm{~cd}$ \\
NZ.1001 & 3 & $34,78 \mathrm{~d}$ \\
S.62.012 & 3 & $31,06 \mathrm{~d}$ \\
Akkavak & 3 & $31,06 \mathrm{~d}$ \\
\hline
\end{tabular}

Duncan testi $(\alpha=0,05$ önem düzeyi)

Karekök dönüşümü yapılan verilere uygulanan Duncan testinde (Tablo 11.) okaliptüs, Fırat kavağı, karakavağın Kocabey klonu, S.62.012 no’lu söğüt klonu ve akkavak farksız olarak ilk grupta yer ala-

Tablo 10. Klon ve orijinlerin böcek zararına ilişkin varyans analizi

Table 10. Variance analysis for insect demages of clones and origins

\begin{tabular}{lccc}
\hline $\begin{array}{c}\text { Varyasyon kaynağ1 } \\
\text { (Böcek zararı) }\end{array}$ & SD & KO & F \\
\hline Klonlar ve Orijinler & 8 & 0,354 & $11,917 * * *$ \\
Blok & 2 & 0,086 & $2,893 \mathrm{~ns}$ \\
Hata & 16 & 0,030 & \\
Genel & 26 & & \\
\hline$\alpha=0,05$ önem düzeyi & & &
\end{tabular}

rak böcek zararına karşı en fazla direnç gösteren klonlar ve orijinler olmuşlardır. Böceklenmeye karşı en hassas NZ.1001 ve S.84.003 no'lu söğüt klonları ile karakavağın Anadolu klonu olmuştur.

\subsection{Deneme sahasında yapılan diğer gözlemlere ilişkin bulgular}

Deneme sahasında ölçümler sonucu elde edilen verilerin değerlendirilmesi yanında, elde edilen bu verilerden bir kısmını açıklayıcı nitelikte olan ve özellikle türlerin yaşama yüzdesi ile gelişimini etkileyen etmenlere ilişkin gözlemlerde yapılmıştır (Tablo 12).
Tablo 11. Klonların ve orijinlerin böcek zararı bakımından Duncan testi ile karşılaştırılması

Table 11. Comperison of clones and origins according to insect damage using Duncan test

\begin{tabular}{lcc}
\hline Klonlar ve orijinler & N & Böcek Zarar1 \\
\hline Okaliptüs & 3 & $1,097 \mathrm{a}$ \\
Firat kavağ1 & 3 & $1,087 \mathrm{a}$ \\
Kocabey & 3 & $1,050 \mathrm{ab}$ \\
N.62.012 & 3 & $1,043 \mathrm{ab}$ \\
Akkavak & 3 & $0,940 \mathrm{ab}$ \\
N.92.126 & 3 & $0,730 \mathrm{bc}$ \\
N.84.003 & 3 & $0,550 \mathrm{~cd}$ \\
Anadolu & 3 & $0,390 \mathrm{~d}$ \\
NZ.1001 & 3 & $0,350 \mathrm{~d}$ \\
\hline$\alpha=0,05$ önem düzeyi & &
\end{tabular}

Tablo 12. Deneme sahasında türleri etkileyen bazı biyotik ve abiyotik faktörlere ait gözlemler

Table 12. Observations for some biotic and abiotic factors affecting species in experiment site

\begin{tabular}{lccccc}
\hline Tür & $\begin{array}{c}\text { Böcek } \\
\text { zararı }\end{array}$ & $\begin{array}{c}\text { Güneş } \\
\text { yanığı }\end{array}$ & $\begin{array}{c}\text { Don } \\
\text { etkisi }\end{array}$ & $\begin{array}{c}\text { Yüksek } \\
\text { taban } \\
\text { suyu }\end{array}$ & $\begin{array}{c}\text { Ağır } \\
\text { toprak }\end{array}$ \\
\hline Okaliptüs & - & Kismen & + & - & - \\
Firat kavağı & - & - & $?$ & - & - \\
Karakavak & + & - & - & Kismen & + \\
Söğ̈ü & + & + & - & $?$ & + \\
Akkavak & - & $?$ & - & Kismen & + \\
\hline
\end{tabular}

-: Etki yok, +: Etki var, ? : Etki gözlenmedi

Tablo 12'de görüldüğü gibi, denemeye alınan türleri etkileyen biyotik ve abiyotik etmenlerden denemenin yapıldığ 1 Şanlıurfa Harran yöresinde kavurucu yaz sıcaklıkları özellikle ince kabuklu söğüt gövdelerinin güney-güneybatı yüzeylerinde ciddi yanıklar oluşturmuştur. Türün kambiyum tabakasına ulaşan güneş yanıkları nedeniyle kurumalar gözlenmiştir. Kurumalardan dolayı kök ve dip kısımları canlı kalabilen fertlerde yanık derecesine göre dal ve gövdede kısmi veya tamamen zarar gören ve zayıflayan, kuruyan ağaçlara böcek saldırısı olmuştur. Kurumalardan dolayı söğütlerde gövdenin dip kısımlarından tekrar yeni sürgünler oluşmuştur. Bu şekilde söğütler, tek gövde üzerinde gelişmekten ziyade bir kökten çıkan birçok sürgün ile sürgün öbeği haline gelmiştir. Yanık izlerine söğütlerin yanında okaliptüs orijininde de rastlanmıştır. Ancak, dal veya gövdeyi kurutacak kadar etkili olmamıştır.

İlk y1llarda okaliptüs orijininde görülen kurumala- 
rın başlıca nedeni don etkisinden kaynaklanmış ve tohumdan yetiştirilen taze fidan gövdesinde yanık etkisi de ilk yılda gerçekleşmiştir. Daha sonraki yıllarda gövde kalınlaştıkça güneş yanığı etkileri düşmüştür. Fırat kavağının soğuk kış şartlarının hüküm sürdüğü ve karlı geçen bölgelerde karın da etkisi ile bu türe ait ağaçların kabukları ve ince gövdeleri kararıp kuruma gözlenmektedir. Fırat kavağında kışları genel olarak 1lık geçen Harran yöresindeki deneme sahasında buna benzer bir etkiye rastlanmamıştır.

Fidan yaşama yüzdesini, sağlı̆̆ını ve gelişimini etkileyen etmenlerden biri de ağır toprak şartlarıdır. Genel olarak denemede kullanılan hızlı gelişen türler havadar, kumlu killi balçık, kumlu balçık veya balçık topraklarda rahatlıkla gelişebilmektedir. Ancak, ağır toprak koşulları, özellikle karakavak, söğüt ve akkavakta iyi bir kök sistemi geliştirememe, dolayısıyla gelişim geriliğine bunun yanında zayıf kalarak böcek istilasına karşı dirençsiz bir hale gelmesine neden olmuştur. A ğır toprak koşullarının genel olarak bulunduğu Harran yöresinde okaliptüs ve Fırat kavağ 1 diğer türlere ait klon ve orijinlere göre daha dayanıklı olup iyi bir gelişim göstermişlerdir.

Fidanlarda kurumaya neden olan etkenlerden biri de 1-3 ay süreli durgun su etkisidir. Tarlalarda yoğun sulamalardan dolayı ağır olan toprakta oluşan taban suyu seviyesinin de yükselmesine bağl1 olarak, suya doyan toprakta oluşan durgun su iyi gelişme gösteremeyen akkavak türünde ve kısmen karakavak klonlarında etkili olurken Fırat kavağı ve okaliptüs üzerinde bu etki gözlenmemiştir.

Y1llık olarak ve gün içerisindeki güneşlenme sürelerinin uzun olduğu bu bölgede su ve toprak yapısının da etkisi ile çok yoğun boylu ot baskısı oluşmaktadır. Bu da türlerin özellikle ilk yıllarda büyüme ve gelişmesine ve dolayısıyla yaşama yüzdelerine de etki etmektedir. Denemede kullanılan türler arasında Firat kavağı bu konuda ilk yıllarda oluşan ot baskısına karşı yüksek (\%100) yaşama yüzdesi ile çok daha iyi direnç göstermiştir.

Çalışmada, karakavak ve Fırat kavağı için farklı yaşlarda ortalama hacim ve servet hesaplamasında Birler (2010) ve okaliptüs için Yıldızbakan ve ark. (2007) çalışmalarına göre 5 ve 10 yaşlarında yaklaşık hacim değerleri hesaplanmıştır. Buna göre, 7046 no'lu okaliptüs orijini 5 yaşında ortalama 10 cm'den fazla çap yaparken 4 . bonitette $3 \times 3 \mathrm{~m}$ aralık mesafede okaliptüs, karakavağın Kocabey klonu ve Fırat kavağının ağaç başına ortalama hacimleri sırasıyla $38.9 \mathrm{dm}^{3}, 13 \mathrm{dm}^{3}$ ve $14.9 \mathrm{dm}^{3}$ olmuştur.

\section{Tartışma}

GAP bölgesinde yapılan barajlardan sağlanan suyun kanal ve kanaletler vasitasıyla özellikle Şanlıurfa'nın Harran, Ceylanpınar, Viranşehir ve Akçakale gibi geniş ovalara sahip bölgelerde kullanılmasıyla tarım alanlarından elde edilen verim ve buna bağlı gelir katlanmıştır. Ancak, aşırı ve bilinçsiz kullanılan sular, çoğu alanda tuzlanma ve taban suyu seviyesinin yükselmesi gibi sorunları da beraberinde getirmiştir. $\mathrm{Bu}$ sorunları gidermenin veya hafifletmenin yollarından biri de tarım alanları, kanallar ve yol kenarında bulunan boş tampon alanların tarımsal ormancılik faaliyetlerinde kullanılmasıdır.

Tarla kenarları ile sulamada kullanılan beton sulama kanaletleri arasında bulunan boş alanların ve fazla suların aktarıldığı drenaj kanallarındaki suların değerlendirilmesi, ayrıca sulamadan dolayı yol boylarının ağaçlandırma amaçlı kullanılabilmesi yönünde hızlı gelişen kavak, söğüt, okaliptüse ait farklı tür, klon ve orijinleri bu çalışmada ele alınmıştır. Çalışma sonucunda E. camaldulensis türünün 7046 no'lu orijini başta olmak üzere Fırat kavağı ve karakavağın Kocabey klonunun Şanlıurfa ilinin Harran yöresinde sulama ve drenaj kanalları boyunca yetiştirilebileceği ortaya konmuştur. Su alma imkanı bulunan yol kenarlarında bu türlerle büyük ölçekte bir ağaçlandırma potansiyelinin olduğu önemle belirtilmiştir.

Bölgede, araştırma yaptığımız türlerden bazılarına ait farklı dönemlerde yapılan benzer çalışmalarda önemli bazı hususlar vurgulanmaktadır. Gürses (1998), okaliptüsün uzun süreli yaz kuraklığına rağmen, yüksek taban suyu ve ekstrem soğukların kısa sürdüğü, kireç bakımından zengin orta tuzlu ortamlarda yetişebildiğini tespit etmiştir. Özellikle sulanabilen alanlarda çok iyi gelişim sağladığını ve E. camaldulensis ile E. grandis türlerinin Karabucak orijinlerinin başarılı olduğunu bulmuştur. Çalışmada, okaliptüsün 7046 no'lu orijini su ihtiyac1nın karşılanabildiği Harran yöresinde iyi gelişme gösterdiği ortaya konmuştur. Bu durum, tuzlanan toprakların iyileştirilmesi ve verimli kullanılması yolunu da açmaktadır. Acar (1997) da tuzlu toprakların okaliptüs türleriyle ağaçlandırılması ile toprakta oluşan tuzluluk nedeniyle çoraklaşan toprağın tamamen elden çıkmasının önlenebileceği belirtmiştir. Bölgede, okaliptüsün yanında kullanılabilecek türlerden biri de Fırat kavağıdır. Fırat kavağının tuzluluğu giderdiği ve pH'ı düşürdüğü, rüzgar perdesi olarak kullanıldığı ve bununla birlikte rüzgar perdesi tesisinin genel olarak nisbi rutubeti artırıp yıllık maksimum sicaklık ortalamasını kısmen düşürdüğüne değinilen farklı araş- 
tırma çalışmaları (Ledgard ve Baker, 1992; Shiji, 1994; Uğurlu, 1998; Wang ve ark., 2003; Zeng ve ark., 2009; Junghans ve ark., 2006 gibi) mevcuttur. $\mathrm{Bu}$ durum dikkate alınarak GAP bölgesinde sıra, galeri veya sorunlu alanlardaki plantasyonlarda yüksek yaşama yüzdesi, çap-boy gelişimi gösteren ve tuzluluğa dayanıklı olan Fırat kavağının özellikle erkek fertleri kullanılabilir.

Toplu ve Karatay (2006) tarafindan, yıllık yağışın $150 \mathrm{~mm}$ civarında olduğu ve ekstrem kurak şartların bulunduğu Şanlıurfa- Akçakale yöresinde yapılan yıllık 6 sulamalı koşullarda 5. yıl sonunda yapraklı ve ibreli tür denemesinde dip çap (toprak seviyesinden $10 \mathrm{~cm}$ yukarıda) bakımından Eldar çamı, kızılçam, Halep çamı, adi servi ve tesbih ağacında sırasıyla $2,75 \mathrm{~cm} ; 2,07 \mathrm{~cm} ; 1,9 \mathrm{~cm} ; 1,46$ $\mathrm{cm}$ ve $1,37 \mathrm{~cm}$ gelişme gözlenmiştir. Çalışmamızda ise okaliptüsün 7046 no'lu orijini, Fırat kavağ1 ve karakavağın Kocabey klonunda göğüs çapı bakımından sirasiyla $10,8 \mathrm{~cm} ; 8,3 \mathrm{~cm}$ ve $7,8 \mathrm{~cm}$ gelişme tespit edilmiştir.

Boy bakımından ise Akçakale'deki araştırma çalışmasında eldar çamı, halep çamı, kızılçam, adi servi ve tesbih ağacında sirasiyla $113,9 \mathrm{~cm} ; 86,2$ $\mathrm{cm} ; 79,6 \mathrm{~cm} ; 77,2 \mathrm{~cm}$ ve $66,7 \mathrm{~cm}$ boy gelişmesi sağlanırken çalışmamızda ise okaliptüs, karakavağın kocabey klonu ve Fırat kavağı boy gelişimleri sırasıyla 7,9 m; $6,5 \mathrm{~m}$ ve 5,5 m olmuştur. Bu çalışmada gerek çap ve gerekse boy bakımından daha iyi bir gelişme olduğunu söyleyebiliriz. Yaşama yüzdesi bakımından ise çalışmamızda Fırat kavağı daha yüksek yaşama yüzdesi gösterirken okaliptüs ve karakavağın kocabey klonu, Toplu ve Karatay (2006)'ın çalışmasındaki en fazla yaşama yüzdesine sahip Eldar çamı (\%78) seviyesine yakın, ancak kızılçamın yaşama yüzdesinden daha fazla yaşama yüzdesi göstermiştir. Harran yöresinde yapılan bu çalışmamızdan da görülebileceği üzere, gerek kullanım imkanı ve gerekse tarım yanında ek gelir getirici imkan sunması bakımından kanal boylarının tam plantasyona göre daha avantajlı olduğu söylenebilir.

GAP bölgesinde söğüt klonları çit, kanal ve kanalet boylarında kısmen kullanılabilir. Ancak, başarılı plantasyonlar için taze gövde ve dallarının doğrudan güneş 1şınlarına uzun süre maruz kalmasının önüne geçilmesi, durgun sudan kaçınılması, ilk yıllarda aşırı alt dal ve ara dalların budanmaması, kalın dal kesikleri oluşturulmaması, kesilmesi halinde yara yüzeylerinin macun vb. maddelerle kapatılması ve ilk yıllarda şiddetli rüzgarda devrilme riskine karşı ağaçların kazıklarla desteklenmesi gibi tedbirlerin alınması gerekmektedir. Bunların yanında daha önceki çalışmalar ve yapılan diğer gözlemlere dayanılarak belirtilen kanallar, tarla kenarları ve yollar boyunca, bölgede az da olsa rastlayabildiğimiz kızılçam ve mavi servi gibi ibreli türler ile tesbih ağacı, çınar, dut ve iğde gibi sıcaklığa dayanıklı yapraklı türlere de çeşitlilik yönünden yer verilmesi düşünülebilir.

Deneme sahasında başarılı bulunan türler ile yapılacak ağaçlandırmalarda farklı yıllara göre elde edilecek servet ve hacim artım miktarları, yöredeki ağaçlandırmaların geleceği ve kazanç durumu için çok önem taşımaktadır. Yaptığımız denemede başarılı olan türlerin ortalama gelişim değerleri, karakavak ve Fırat kavağ 1 için yerli karakavak için yapılan Birler (2010)'in çalışması ve okaliptüs için ise Yıldızbakan ve ark. (2007)'e ait çalışmaların okaliptüs baltalıkları için hesaplanan hacim tablolarından yararlanılarak hesaplanmıştır. Birler ve ark. (1995) farklı bir çalışmada, okaliptüsün iyi yetişme ortamında $3 \times 3$ m dikim aralığında genel ortalama artımın en yüksek olduğu yaşın 10 , bu yaştaki meşcere orta çapı $20,1 \mathrm{~cm}$; hektardaki hacmin $245 \mathrm{~m}^{3}$ olduğunu bulmuşlardır. Çalışmamızda 7046 no'lu okaliptüs orijini ise aynı dikim aralıklarında benzer bir performans göstererek 5 yaşında ortalama $10 \mathrm{~cm}$ 'den fazla çapa ulaşmıştır. Beş yılın sonunda 4 . bonitette okaliptüs, Fırat kavağ 1 ve karakavağın Kocabey klonu ağaç başına ortalama hacim olarak $38,9 \mathrm{dm}^{3}, 14,9 \mathrm{dm}^{3}$ ve $13 \mathrm{dm}^{3}$ büyüme göstermiştir.

Çalışmamızdan elde edilen veriler ışığında, Harran yöresinde 3 . ve 4 . bonitetlerde binlerce km uzunluğundaki kanal ve yol boylarında yapılacak okaliptüs ağaçlandırmalarında 10 yılda 6 milyon $\mathrm{m}^{3}$ ten fazla servet elde edilebilmektedir. Bu durum ülke odun emvali üretimine önemli düzeyde katkılar sağlayacaktır.

Bölgede yapılacak ağaçlandırma için emvalin kullanılacağı alana bağlı olarak daha kalın çaplar için daha uzun idare müddetleri gerekecektir. Belirlenen amaçlara göre aralık mesafeler ve idare süreleri değişmekle beraber iyi bonitetlerde daha kısa idare süresi sonunda ve daha yüksek oranda ağaç serveti elde edilebilecektir.

\section{Sonuç ve Öneriler}

Çalışmada, geniş alüviyal bir ovaya sahip Şanlıurfa ilinin Harran ilçesi yakınlarında tarım alanı kenarında sulama kanaletleri boyunca kurulan araştırma çalışmasında karakavak türünün Kocabey, Anadolu ve N.92.126 klonlar1, söğüt türlerine ait N.1001 melezi ile N.84.003 ve N.62.012 klonlar1, akkavak ve Fırat kavağı türleri ile okaliptüsün 7046 no'lu orijinleri kullanılarak 5 yıllık çap, boy, yaşama yüzdesi ve böcek zararı bakımından değerlendirilmiştir. 
Çalışma sonucunda genel olarak okaliptüs türünün (Eucalyptus camaldulensis Dehnh.) 7046 no'lu orijini gerek dip çap ve göğüs çap1, gerekse boylanma bakımından 5. yılın sonunda en iyi gelişimi yapmıştır. Bu tür, çalışma süresi sonrasında da bu gelişimini sürdürmüştür. Nitekim deneme alanında yapılan gözlemde 7 yaşında $30 \mathrm{~cm}$ çap ve 15 m'den fazla boylanma gösteren bireylere rastlanmıştır. $\mathrm{Bu}$ orijinin yanında Firat kavağı, karakavağın Kocabey klonları da iyi gelişme göstererek başarılı bulunmuştur. Akkavak türü ve söğüt klonları ise genel anlamda düşük performans göstermişlerdir.

Çalışmamızda GAP bölgesinde plantasyon olarak ilk defa kullanılan Fırat kavağı başarılı bir tür olarak karşımıza çıkmaktadır. Diğer yandan Fırat kavağının çok sayıda olumlu özelliği yanında 3-5 yıl içerisinde tohum tutmaya başlayan dişi fertlerin tohum yayması nedeniyle kısa sürede çimlenip alana yayılmaması için bu türe ait erkek fertlerin kullanılması veya tohumların Mayıs sonu Haziran başında çimlenmesinin ardından alanın sürülmesi bu olumsuzluğu giderecektir.

$\mathrm{Bu}$ çalışma ile GAP bölgesinde sulanabilen uygun tarla kenarları ile kanal, kanalet ve sulanabilen yol kenarlarında ağaçlandırmalarda temel obje olan ağaç türlerinden, sıra veya galeri şeklinde okaliptüs türünün 7046 no'lu orijini, Frrat kavağ1 ve karakavak türünün 77/10 no'lu Kocabey klonlarının kullanılabileceği ortaya konmuştur. GAP bölgesinde bu türlerle yapılacak plantasyonlarda özellikle okaliptüs türü için bölge ovalarında don etkisinin dikkate alınması gerekmektedir.

GAP kapsamında büyük oranda sulu tarıma geçen ve alan olarak büyük bir bölümü kaplaması bakımından Harran/Şanlıurfa yöresi ile birlikte Ceylanpınar, Viranşehir, Akçakale gibi öncelikle Şanlıurfa'nın güney kesimleri ve daha sonra orta bölgelerinin, tarımın yanında ağaçlandırma alanları olarak değerlendirilme imkanı vardır.

$\mathrm{Bu}$ araştırma sonuçlarına dayanılarak başarılı olan hızlı gelişen türlerle sulu koşullarda tesis edilecek endüstriyel plantasyonlardan elde edilecek odun hammaddesi üretimi yaygın etki ile gelecekte çok önemli boyutlara ulaşacak ve odun ve odun ürünleri gereksinimi Bölge içinden karşılanabilecek duruma gelecektir. Bu kapsamda, tarım alanları çevresinde uygun durumdaki boşluklarda tek sıra, iki sıralı veya galeri şeklinde ağaçlandırmalar yapilabilir.

$\mathrm{Bu}$ ağaçlandırmalar odun ürünü yanında özellikle Fırat kavağı ve okaliptüsün tuzlanma görülen bölgelerde tuzu bünyesine alarak tuzlanmanın azalmasina ve yüksek taban suyu seviyesini düşürerek tekrar tarım yapılmasına imkan sağlaya- caktır. Bunun yanında bölgede bu türlerle kurulan plantasyonlar, drenaj kanallarından nehir büyüklüğünde boşa akıp giden suları tarla kenarlarında kullanarak yarayışlı hale getirmektedir. Bunların yanında bölgede yüksek sıcaklık ve kurutucu rüzgarların etkisini azaltarak verimin artmasını sağlayan rüzgar perdesi görevini görmektedir. Ayrıca, agroforestry imkanı sağlayarak yapraklarından hayvan yemi, dallarından yakacak, sıcak ortamda gölgelenme, kuşlar için bir yaşam ortamı ve peyzaj etkileri bulunmaktadır. Bölgede yapılacak ağaçlandırma çalışmaları tüm GAP bölgesine yaygınlaştırılması durumunda yaygın etkiler kendini gösterecektir.

Plantasyonlarla idare süreleri sonunda odun ürünleri elde edildikçe bu gelişmeler bu alanlardan elde edilecek odun emvalini kullanacak sanayilerin gelişmesine, yeni iş kollarının açılmasına, odun üretim, taşıma, işleme, yarı mamul ve mamül mal üretimi, mobilya sanayinin kurulması gibi önemli katkılar sağlayacaktır. Dolayısıyla bu durum yeni ve çeşitli iş imkanları ile işsizliğin azaltılmasına ve bölgenin kalkınması ile ülke ekonomisine büyük yararlar sağlayacaktır. Bu olumlu gelişmelerin diğer bir etkisi de Bölgeye yakın ormanlar üzerindeki baskıların azalmasına ve üretimin sağlam temellere dayanmasıyla oluşacak devamlı üretim süreci başlangıçta bu Bölgede ve sonra diğer bölgelerde etkisi görülerek sürdürülebilir ormancılığın yerleşmesine imkan verecektir.

Ayrıca, kurak çöl ikliminin hakim olduğu Bölgenin sinırında bulunan ve sulanabilen GAP bölgesinde, endüstriyel plantasyonlara yapılacak doğru yatırımlarla komşu ülkeler için vazgeçilmez bir odun ürünleri ve sanayi cazibe merkezi haline gelecek ve bu ülkelere ihracat firsat ve avantajları ortaya çıkacaktır.

\section{Teşekkür}

Makale; Orman Genel Müdürlüğü, GüneydoğuAnadolu Ormancılık Araştırma Enstütüsü Müdürlüğü tarafından yürütülen 24.1712 (2007-2012) numaralı “GAP Bölgesinde Sulama Kanaletleri Boyunca Yapılacak Ăgaçlandırmalarda Kullanılabilecek Bazı Hızlı Gelişen Yapraklı Türlerin Belirlenmesi" adlı projeden yararlanılarak hazırlanmıştır. Projenin yürütüldüğü arazinin sahibi Abdulgafur KILIÇ ve ailesine desteklerinden dolayı teşekkür ederiz.

\section{Kaynaklar}

Acar, C., 1997. Tuzlu topraklarda kullanılabilecek bazı ağaç türleri. Ege Ormancıllk Araştırma Enstitüsü, Enstitü Dergisi No: 1997/1, ISSN: 1300-9532, s: 84-107, İzmir.

Ager, A. Ronnberg, A. C. Thorsen, J., Siren, G., 1986. 
Genetic improvement of willows for energy forestry in Sweden. Swedish university of agricultural sciences, deparment of ecology and environmental research, Section of Energy Forestry, Uppsala, s.4, 47 s.

Anonim, 2004. Su dünyas1, Mart 2004. Dergi say1 8, sayfa $38-43$.

Anonim, 2006. DSİ Genel Müdürlüğü 2006 yılı faaliyet raporu. http://www.dsi.gov.tr/ (Erişim tarihi: 15.08.2013)

Anonim, 2012. 2012 y1l1 faaliyet raporu. DSİ Genel Müdürlüğ̈̈, http://www.dsi.gov.tr/ (Erişim tarihi: 15.08.2013)

Anonim, 2013a. http://www.fao.org/forestry/ (Erişim tarihi: 05.09.2013)

Anonim, 2013b. http://tr.wikipedia.org/wiki/ Dosya:Latrans-Turkey location (Erişim tarihi: 19.08.2013) (Türkiye Haritası).

Anonim, 2013c. Harran/Koruklu istasyonu meteorolojik verileri, Şanlıurfa Toprak ve Su Kaynakları Araştırma Enstitüsü.

Anonim, 2015. Türkiye orman varlığ 2015 . Orman ve Su İşleri Bakanlığı Orman Genel Müdürlüğü. https:// www.ogm.gov.tr/ekutuphane/Yayinlar/ (Erişim tarihi: 08.09.2017)

Anonim, 2017. IBM SPSS statistics. http://spss-64bits. en.softonic.com/ (Erişim tarihi: 07.11.2017)

Aslan, S. 1991. Güneydoğu Anadolu Bölgesi'nde iyi gelișim gösteren bazı iğne yapraklı ağaç türlerinin seçimi (1988 Yılı sonuçları), Ormancılık Araştırma Enstitüsü Yayınları., Teknik Bülten No: 216, ODC. 232, Ankara.

Aslan, S., Gökdemir, Ş., 2005. "GAP Bölgesi ağaçlandırmalarında kullanılabilecek bazı iğne yapraklı tür ve orijinler" http://sura.cevreorman.gov.tr/ (Erişim tarihi: 18.10.2015).

Ayberk, S. 1996. Ağaçlandırma ve enerji ormanı alanlarında tarımsal ormancılık uygulamaları üzerine araştırmalar. Kavak ve Hızlı Gelişen Tür Orman Ağaçları Araştırma Müdürlüğü, Araştırma Dergisi, 1996/1, Seri No: 23, ISSN: 1300-3941, s.1-17, İzmit.

Aydoğdu, M. H., 2006. Güneydoğu Anadolu Projesi (GAP), kapsamındaki su kaynakları ve sulama-drenaj sistemlerinin değerlendirilmesi. Harran Üniv. Fen Bil. Enst., İnşaat Mühendisliği ABD., Yüksek Lis. Tezi, s. 89, Şanliurfa.

Birler, 2010. Türkiye'de kavak yetiştirme (fidanlıkağaçlandırma-koruma-hasılat-ekonomi-odun özellikleri) Kavak ve Hızlı Gelişen Orman Ağaçları Araştırma Müdürlüğü, ISSN: 1300-395, Müdürlük Yayın No: 262, İzmit.

Birler, A. S., Koçer, S. 1992. Güneydoğu Anadolu Projesi (GAP) gölgesinde kavak yetiştiriciliğinin optimizasyonu ve sosyo ekonomik önemi. Kavak ve Hızlı Gelişen Tür Orman Ağaçları Araştırma Enst. Çeşitli Yay. Serisi No:1, İzmit.

Birler, A. S., Koçer, S., Avcıŏglu, E., Diner, A., Gürses,
M. K. ve Gülbaba, A. G., 1995. Okaliptüs ağaçlandırmalarında hacim ve kuru madde hasılatı. Kavak ve Hızlı Gelişen Yabancı Tür Orman Ağaçları Araştırma Enstitüsü, Teknik Bülten No: 171, 1995/1, İzmit.

Dinç, U., Şenol, S., Satın, M., Kapur, S., Güzel N., Derici. R., Yeşilsoy, M. Ş., Yeğingil, İ., Sarı., M., Kaya, Z., Aydın, M., Kettaş, F., Berkman., A., Çolak, A. K., Yılmaz, K., Tunçgöğüs, B., Çavuşgil, V., Özbek, H., Gülüt , K.Y., Kahraman, C., Dinç, O., Kara, E.E, 1988. Güneydoğu Anadolu Toprakları (GAP), I. Harran Ovası, TÜBİTAK, TOAG 534, Kesin Sonuç Raporu, Ankara

Ercan, M., 1997. Bilimsel araştırmalarda istatistik. Kavak ve Hizlı Gelișen Orman Ağaçları Araștırma Enstitüsü Müdürlüğü, Çeşitli Yayınlar Serisi No: 6, ISSN 1300-3933.

Ericsson, T., 1984. Nutrient cycling in willow. International energy agency /ENFORI joint report. Canadian Foresty Service, s.2, $32 \mathrm{~s}$.

Gülbaba, G., 1990. Okaliptüs yapraklarından elde edilen eterik yağlar, kullanım yerleri ve yaprak işletmeciliği. Türkiye'de Okaliptüs yetiştiriciliği'nin 50. y1lı, Kavak ve Hızlı Gelişen Yabancı Tür Orman Ağaçları Araștırma Enstitüsü Dergisi. 1:.51-64

Gürses, M. K. 1998. Okaliptüsler (Eucalyptus camaldulensis Dehn., Eucalytus grandis W. Hill ex Maiden) ile endüstriyel ağaçlandırma teknikleri, Doğu Akdeniz Ormancık Araştırma Enstitüsü, Enstitü Dergisi, Sayı: 4, ISSN 1300-8540, S: 1-16, Tarsus.

Gürses, M.K., 1992. Türkiye'de Okaliptüsün orman ürünleri endüstrisindeki yeri ve önemi, 1. Ulusal Orman Ürünleri Endüstri Kongresi, KTÜ, Trabzon.

Junghans, U., Polle, A., Düchting, P., Weiler, E., Kuhlman, B., Grube, F. and Teichmann, T., 2006. Adaptation to high salinity in poplar involves changes in xylem anatomy and auxin physiology. Plant, Cell and Environment, 29, 1519-1531. doi: 10.1111/j.1365-3040.2006.01529.x

Karsavuran, Y., Ayvaz, A. ve Doğanlar, M., 2007. Türkiye'de okaliptüs ağaçlarında saptanan zararlı hymenopterler, tanımları, zarar șekilleri, biyolojileri, ekonomik önemleri ve mücadele yöntemleri. Türkiye'de Ormanc1lık Eğitiminin 150. Y1l1, Uluslararası Sempozyum. s. 635-645, İstanbul.

Ledgard, N. J. ve Baker, G. C., 1992. Tree shelter trials for 1rrigated pastures. Fr1 Contact Report. FWE 92/11. New Zealand Milne. P 1985. Shelterbelts in Canterburry. Why? What Sort? How Many? and Where. FRI Leaflet 5. Chistchurch. New Zealand.

Myburg, Z., Grattapaglia, D., Potts, B., Labate, C., Bossinger, G., Byrne, M., Vaillancourt, R., Sederoff, R., Southerton S., Members of Eucagen, 2006. Sequencing of the Eucalyptus genome: a proposal to doe-jg1, eucagen (Eucalytpus Genome Network).

Öner, N. 2002. Çankırı ilinin kuraklık bakımından kritiği ile ağaçlandırmalarda kullanılabilecek türler ve ağaçlandırma teknikleri. Kırsal Çevre Y1llı̆̆ 2002 , ISSN 1303-9334, Kırsal Çevre ve Ormancılık Sorunları Araştırma Derneği, Ankara. 
Shiji, W. 1994. The status of Populus euphratica in China. The Research Institute of Forestry Chinese Academy of Forestry Wan Shou Shan 100091, Beijing, China.

Toplu, 1997. Güneydoğu Anadolu Bölgesi (Diyarbakır) Melez Kavak Birinci Aşama Klon Denemesi Sonuçları. GDA Ormancılık Arş. Enstitü Dergisi, Cilt:1, Sayı:1, s. 45-59 (90), Elazığ.

Toplu, F. 1998. GAP Bölgesinde endüstriyel plantasyonlara uygun hızlı gelişen ağaç türleri ile ilgili çalışmaların dünü, bugünü ve yarını. Hızlı gelişen türlerle yapılan ağaçlandırma çalışmalarının değerlendirilmesi ve yapılacak çalışmalar workshop. Orman Bakanlığı Yayın Dairesi Başkanlığı Yay. No:083, s. 347-353, Ankara.

Toplu, F., Karatay, H. 2006. Gap Bölgesinde farklı sulama koşullarında tesis edilecek ağaçlandırmalarda kullanılabilecek tür seçimi (Akçakale Örneği). GDA Ormancılık Araștırma Müdürlüğü, Teknik Bülten No: 10, Orman Bak. Yay. No: 291, ISSN: 1301-9538, ODC: 232.1. Elazı̆̆.

Toplu, F., Uğurlu, S., Erkan, N., Karatay, H., 2001. GAP Bölgesinde Karakavak (Populus nigra L.) klonlarının fidanlık performansları. Güneydoğu Anadolu Ormancılık Araştırma Enstitüsü, Teknik Bülten No: 7. ISSN 1301-

\section{8, Elazı $\breve{g}$.}

Uğurlu, S. 1998. GAP Yöresinde rüzgar perdeleri tesisi için kullanılabilecek türlerin tespiti, GDA Ormancılık Araştırma Müdürlüğü, Teknik Bülten No: 5, ODC: 266, ISSN: 1301-9538, Elazığ.

Wang, W., Vinocur, B. and Altman, A., 2003. Plant responses to drought, salinity and extreme temperatures: towards genetic engineering for stress tolerance, Planta 218, 1-14.

Yaltırık, F. ve Efe, A. 2000. Dendroloji Ders Kitabı, Gymnospermae - Angiospermae, İstanbul üniversitesi yayın No: 4265, Orman Fakültesi, ISBN 975-404-594-1, Istanbul.

Yıldızbakan, A., Saraçoğlu ve Ö. Özkurt, A., 2007. Okaliptüs (Eucalypus camaldulensis Dehn.) baltalıklarında hacim ve kuru madde hasılat araştırmaları. Doğu Akdeniz Ormancılık Araştırma Enstitüsü. Teknik Bülten No: 27. ISBN:978-605-393-024-2, Tarsus.

Zeng, F., Yan, H. and Arndt, S., K., 2009. Leaf and whole tree adaptations to mild salinity in field grown $\mathrm{Po}$ pulus euphratica. Tree Physiology, 29, 1237-1246. doi: 10.1093/treephys/tpp055. 